\title{
The impact of artificial intelligence and digital style on industry and energy post-COVID-19 pandemic
}

\author{
Abbas Sharifi ${ }^{1}$ (D) Mohsen Ahmadi $^{2} \cdot$ Ali Ala $^{3}$ \\ Received: 17 February 2021 / Accepted: 30 June 2021 / Published online: 16 July 2021 \\ (C) The Author(s), under exclusive licence to Springer-Verlag GmbH Germany, part of Springer Nature 2021
}

\begin{abstract}
The SARS-CoV-2 virus caused crises in social, economic, and energy areas and medical life worldwide throughout 2020. This crisis had many direct and indirect effects on all areas of society. In the meantime, the digital and artificial intelligence industry can be used as a professional assistant to manage and control the outbreak of the virus. The present article's objective is to investigate the effects of COVID-19 on each of the various fields of medicine, industry, and energy. What sets this article apart is studying the impact of artificial intelligence and digital style on reducing the damage of this fatal virus. Energy and related industries are of the areas affected by the SARS-CoV-2 virus. The most exciting approach in this article is to encourage countries with economies based on non-renewable energy to develop solar and wind energies. Renewable energies can operate well in the event of another phenomenon such as COVID-19 and reduce the virus's destructive effects and lead to economic prosperity.
\end{abstract}

Keywords Artificial intelligence $\cdot$ Digital style $\cdot$ Energy $\cdot$ Industries $\cdot$ COVID-19 pandemic

\section{Introduction}

The new coronavirus SARS-CoV-2, known as COVID-19, was introduced by the World Health Organization (WHO) in late 2019. Since late December, it has spread rapidly from Wuhan, China, to other countries and led to a worldwide pandemic. The disease has caused unprecedented shortages in healthcare, care equipment, and many other industries. COVID-19 placed restrictions on the supply of raw materials in traditional style industries. However, a small number of these shortcomings were detected in digital industries under Industry 4.0. Some industries, such as intelligent sensors, nanotechnologies, Internet of Things and blockchain technologies, and artificial intelligence, operated with high success

Responsible Editor: Philippe Garrigues

Abbas Sharifi

Abbas.Sharifi@mee.uut.ac.ir

1 Department of Mechanical Engineering, Urmia University of Technology (UUT), Urmia, Iran

2 Department of Industrial Engineering, Urmia University of Technology (UUT), Urmia, Iran

3 Department of Industrial Engineering and Management, Shanghai Jiao Tong University, Shanghai, China
(Bragazzi 2020; Kulachinskaya et al. 2020; Wang et al. 2020). In the last 20 years, scientists and physicians have shown more interest in artificial intelligence (AI) technologies. First of all, many have attempted to provide a precise definition of artificial intelligence.

According to some authors, artificial intelligence is a machine's capacity to decode and understand the input in an intelligent system. Some believe that artificial intelligence is a novel method of managing information in a business model (Lüdeke-Freund 2010). According to Schilirò (2020), artificial intelligence can be divided into five broad categories: (1) computer vision, (2) natural language, (3) virtual assistant, (4) robotic process automation, and (5) Advanced Machine Learning. Digitalization significantly affects global trade and investment. Moreover, digital data and information are new concepts that can be considered similar to new oil resources today. More work completed on this issue leads to the improvement of solutions to global problems. Furthermore, data, ideas, technologies, and best practices in this field affect investors' decisions worldwide, which turn into opportunities to monetize data. At the global level, this information has significantly contributed to the increase in world GDP over the past decades, and technologies based on artificial intelligence and digital show a more significant share of the impact on growth than the global trade in goods (Schilirò 2020). In the present study, the authors attempt to examine the technologies, effects 
of artificial intelligence, and the process of digitalization on communities after the outbreak of the COVID-19 virus. For this purpose, the authors first discuss the applications of this model of technology in education and treatment. Afterward, the programs and works performed in this area are introduced. Then the authors investigate the entry of this field into industries and companies. Finally, the impact of this industry on energy is reviewed (see Fig. 1).

The COVID-19 pandemic has had an impact on energy consumption, markets, and technology and will continue to do so. Despite the fact that the epidemic has wrecked devastation on human civilization, it will enable a quick growth in renewable energy, which will contribute to long-term growth. The building of renewable infrastructures will help speed up the post-pandemic economic restoration. Building on a broadbased and distributed energy storage system will be an important way to ensuring energy supply security depending on the renewable-dominated system. AI technology, which were essential in combating the epidemic, will also aid in the future growth of energy by making it more clean, efficient, and intelligent. The influence and use of artificial intelligence instruments and digital style on industry and energy following the outbreak of COVID-19 is explored in this paper using recent study material.

\section{Effects of artificial intelligence and the digitalization process after COVID-19}

\section{Technology in education, disease prevention, and treatment}

The digital technologies and technologies under the title of the Fourth Industrial Revolution have assisted in providing distance education, remote monitoring system, and sending information from distant places to health bases (Javaid et al. 2020). The video surveillance based on artificial intelligence and machine vision effectively reduced the work of doctors and hospital managers in these critical situations. Digital technologies offer methods for the proper isolation of infected patients to reduce the high risk of mortality, accelerate drug production, treatment, and care, which may also contribute to epidemics similar to COVID-19 in the future (Javaid et al. 2020). With the outbreak of COVID-19 and the increase in mortality, scientists worldwide are looking for new technologies to screen infected patients at different stages, find the best clinical trials, control the spread of the virus, etc. Recent studies have revealed that machine learning and artificial intelligence are more promising, faster, and more reliable technologies than humans in healthcare. In this regard, it should be noted that not all technologies are intended to remove humans from the cycle of interactions in the medical industry but to provide accurate decisions to physicians (Lalmuanawma et al. 2020). Although it is uncertain how carbon emissions would affect the planet after the COVID-19 outbreak, the energy intensity effect and the economic structure effect have opposing effects on carbon intensity drop, respectively, accelerating and delaying it. The energy mix effect, on the other hand, has a minimal impact on carbon intensity reduction. The outcomes of the deconstruction of industrial carbon intensity demonstrate that technological and structural factors varied greatly between industries.

\section{A short brief explanation of rehabilitation and the effect of medicine over the COVID-19}

Our healthcare system relies heavily on rehabilitation. Even so, during a pandemic response, when the healthcare system's attention switches to the wise management of a surge of severely ill people, it is highly vulnerable. During the rapid growth of the COVID-19 pandemic, the problems of altering the roles of treatment providers and systems reveal insights that may help systems manage their reactions as they deal with these concerns. The impacts of the pandemic will last well beyond the immediate emergency response. Preparing for future pandemics is a critical long-term strategy for maximizing our ability to react to future problems in our healthcare system's rehabilitation services. Infection prevention and control methods and supportive care, such as supplemental oxygen and mechanical ventilatory support, are being used in the treatment of COVID-19. The US Food and Drug
Fig. 1 Review and discussion hierarchy
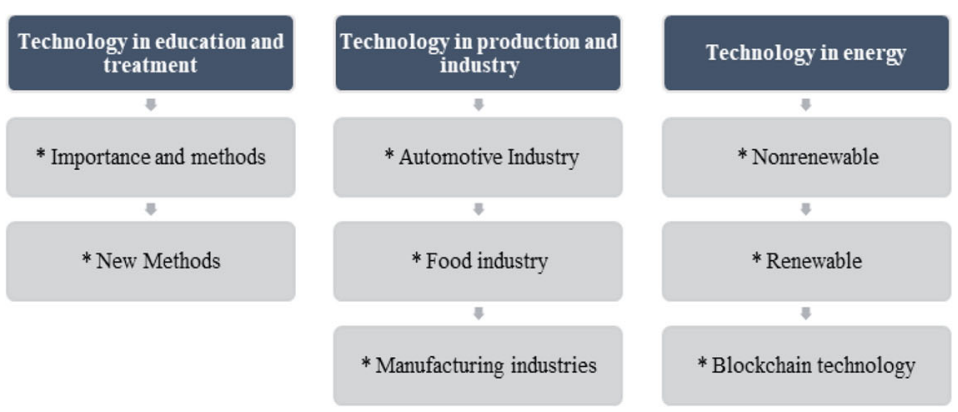

Result and suggestion
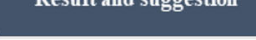
Administration (FDA) has authorized remdesivir (Veklury) to treat COVID-19 in some circumstances.

\section{The advantages of Industry 4.0 technologies over the COVID-19 crisis}

Javaid et al. (2020) describe the effects of the Fourth Industrial Revolution on coronavirus prevention. Artificial intelligence and new technologies have also been effective in preventing coronavirus disease. This critical movement is including the use of virtual reality by physicians and medical staff to reduce the risk of coronavirus disease, which is applied to create a completely stress-free environment for training medical staff (Haleem and Javaid 2019; Ren et al. 2020).

Artificial intelligence for COVID-19 crisis management initially helped people with thermal imaging equipment scan public spaces, which could be used for social distancing. The infrared cameras were used to monitor crowds at airports, public places, and train stations across China. These cameras are also applied to detect the faces of people with a high fever. They can scan 200 people per minute and see people with body temperatures higher than $37.3^{\circ}$ under the pretext that they may suffer from the disease (Naudé 2020). Imagine a time when there was a crisis similar to COVID-19, and there was no possibility of using these technologies. In such cases, due to a lack of sufficient information about this disease, people would maintain social relations with each other and use traditional findings for their treatment.

On the other hand, doctors would treat patients with simple laboratory facilities and devices. Also, in the corridors of medical centers and hospitals, people would be move with high density. Hence, the result would be nothing but the spread of the virus and the increase in infections and deaths due to COVID-19. However, nowadays, with digital technologies and modern technologies, advanced image processing cameras can be used in medical centers' corridors to distinguish people suspected of being infected. Industry 4.0 technologies can be described as professional assistants for all community sections (see Table 1). The most important applications of this technology on COVID-19 are as follows:

- Prevention and deceleration of the spread of disease

- Providing treatment strategies and various methods in the diagnosis of COVID-19

- Equipping and improving the supply chain of healthcare industries

- Integrated control and monitoring of medical centers and public places

- Significant reduction in virus infection and death due to COVID-19
Table 1 Industry 4.0 technologies during the COVID-19 outbreak (Haleem and Javaid 2019; Ren et al. 2020; Naudé 2020)

\begin{tabular}{|c|c|c|}
\hline Technology & Description & What helps? \\
\hline $\begin{array}{l}\text { Machine } \\
\text { learning }\end{array}$ & $\begin{array}{l}\text { Machine vision and deep } \\
\text { learning is an approach to } \\
\text { analyze data and develop } \\
\text { analytical models for a } \\
\text { system. It is based on the } \\
\text { fact that the system can } \\
\text { understand information } \\
\text { from data, identify the } \\
\text { models alone, and make } \\
\text { the final decision with } \\
\text { minimal human } \\
\text { intervention } \\
\text { This technology can be } \\
\text { highly effective in quality } \\
\text { control, evaluation, } \\
\text { manufacturing, and } \\
\text { production }\end{array}$ & $\begin{array}{l}\text { Machine learning was used } \\
\text { in all video surveillance } \\
\text { systems after COVID-19 } \\
\text { and significantly contrib- } \\
\text { uted to controlling people } \\
\text { suspected of being infect- } \\
\text { ed with the coronavirus. } \\
\text { This technology was also } \\
\text { used in most other tech- } \\
\text { nologies to stimulate and } \\
\text { convert human com- } \\
\text { mands into machine lan- } \\
\text { guage }\end{array}$ \\
\hline $\begin{array}{l}\text { Intelligent } \\
\text { sensor }\end{array}$ & $\begin{array}{l}\text { Intelligent sensors are } \\
\text { applied in some cases, } \\
\text { such as reading details } \\
\text { and features, measuring } \\
\text { predicted failure, } \\
\text { surveillance, monitoring, } \\
\text { and increasing system } \\
\text { performance. Small } \\
\text { sensors are used in } \\
\text { wearable gadgets and } \\
\text { wireless technologies to } \\
\text { activate the IoT industry } \\
\text { and dynamics }\end{array}$ & $\begin{array}{l}\text { Sensors could play the most } \\
\text { crucial role during the } \\
\text { COVID-19 crisis out- } \\
\text { break because the disease } \\
\text { was transmitted through } \\
\text { hand contact, etc. With } \\
\text { sensors connected to } \\
\text { electronic kits or mobile } \\
\text { applications, it signifi- } \\
\text { cantly avoided contami- } \\
\text { nated contact }\end{array}$ \\
\hline $\begin{array}{l}\text { Mobile } \\
\text { technolo- } \\
\text { gy }\end{array}$ & $\begin{array}{l}\text { It is not possible without } \\
\text { Industry } 4.0 \text { technology } \\
\text { and mobile technology. } \\
\text { The use of this } \\
\text { technology often } \\
\text { constitutes the waking } \\
\text { time of each person. It } \\
\text { contains computing chips } \\
\text { and grids and a variety of } \\
\text { sensors suitable for data } \\
\text { analysis }\end{array}$ & $\begin{array}{l}\text { Smartphones are } \\
\text { undoubtedly the only } \\
\text { low-cost, accessible, and } \\
\text { safe method of } \\
\text { communication in the } \\
\text { case of this disease, which } \\
\text { somehow tried to learn } \\
\text { and make some } \\
\text { experimental tests and } \\
\text { reduce people's contact } \\
\text { with the community } \\
\text { through the various } \\
\text { sensors on it }\end{array}$ \\
\hline $\begin{array}{l}\text { Internet of } \\
\text { Things }\end{array}$ & $\begin{array}{l}\text { This technology sends data } \\
\text { to a centralized server for } \\
\text { analysis. This data is the } \\
\text { same data transmitted to } \\
\text { the server through devices } \\
\text { connected to the Internet, } \\
\text { such as mobile phones } \\
\text { and robots. The Internet } \\
\text { of Things can be the best } \\
\text { option for digitizing a } \\
\text { business, industry, or } \\
\text { various places associated } \\
\text { with increased wealth, } \\
\text { efficiency, and } \\
\text { productivity }\end{array}$ & $\begin{array}{l}\text { In times of crisis, this option } \\
\text { could be used to automate } \\
\text { factories, homes, etc., by } \\
\text { connecting to smart } \\
\text { sensors to reduce contact } \\
\text { and communication with } \\
\text { objects in any place and } \\
\text { intelligently control and } \\
\text { execute them remotely. } \\
\text { This technology has also } \\
\text { been able to obtain } \\
\text { various information about } \\
\text { each region's population } \\
\text { and traces the outbreak's } \\
\text { source during this period } \\
\text { with the data obtained } \\
\text { through people's } \\
\text { smartphones }\end{array}$ \\
\hline
\end{tabular}


Table 1 (continued)

\begin{tabular}{|c|c|c|}
\hline Technology & Description & What helps? \\
\hline $\begin{array}{l}\text { Cloud } \\
\text { comput- } \\
\text { ing }\end{array}$ & $\begin{array}{l}\text { This technology can be used } \\
\text { for easy network access to } \\
\text { various computing } \\
\text { resources such as servers, } \\
\text { storage, applications, and } \\
\text { services }\end{array}$ & $\begin{array}{l}\text { Throughout the COVID-19 } \\
\text { era, this technology made } \\
\text { life in quarantine easier } \\
\text { for people in the commu- } \\
\text { nity through cloud ser- } \\
\text { vices over the Internet. } \\
\text { Additionally, people dur- } \\
\text { ing this period should use } \\
\text { applications in this field } \\
\text { for health and treatment } \\
\text { measures }\end{array}$ \\
\hline $\begin{array}{l}\text { Virtual } \\
\text { reality }\end{array}$ & $\begin{array}{l}\text { This technology consists of } \\
\text { a gadget that is covered } \\
\text { on the eyes. The } \\
\text { technology used in this } \\
\text { gadget can be } \\
\text { implemented for } \\
\text { dedicated applications. In } \\
\text { this technology, the } \\
\text { environment is usually in } \\
\text { an environment with } \\
\text { computer graphics and } \\
\text { 3D models and allows } \\
\text { people's virtual presence }\end{array}$ & $\begin{array}{l}\text { People's social connections } \\
\text { were affected at the onset } \\
\text { of the COVID-19 crisis. } \\
\text { On the one hand, people } \\
\text { needed to have these } \\
\text { connections spiritually. } \\
\text { On the other hand, with } \\
\text { the outbreak of the } \\
\text { problem, the medical staff } \\
\text { faced a challenge, and } \\
\text { people required basic } \\
\text { training when dealing } \\
\text { with a crisis. Virtual real- } \\
\text { ity provided this } \\
\text { non-physical connection. } \\
\text { As a result, medical staff } \\
\text { used the technology for } \\
\text { distance education to re- } \\
\text { duce the disease inci- } \\
\text { dence. People also used } \\
\text { this technology for } \\
\text { friendly communication } \\
\text { or work }\end{array}$ \\
\hline
\end{tabular}

\section{Mobile applications and helping to solve the COVID- 19 crisis}

One of the categories of Industry 4.0 is mobile technology, which is the article's title due to its high importance. Regardless of the type of operating system and features, mobile technologies are of great importance in people's daily lives (Javaid et al. 2020). In the post-COVID-19 era, this technology is efficient and valuable. Since addressing mobile health service needs is the only acceptable way to connect to the rest of the world, facilities, sensors, and chips can also control the issue. Smartphones, without a doubt, are based on these operating systems. In today's medical industry, various countries make use of innovative technologies.

For example, Germany has implemented a tracking program based on smartwatches, which uses pulse and temperature. It transmits the resulting data to areas of health bases for further analysis (Heidel et. al. 2020). This feature has been applied in a limited and experimental way to evaluate people with coronavirus disease. People are split into information assets by location in this method. The smartwatch user may develop coronavirus disease due to changes in the reference program, such as pulse and temperature.

In the same way, that area is under the control of the health staff. With this system, individuals' incidence and the speed of disease transmission can be significantly assessed (Whitelaw et al. 2020). Every country takes the importance of mobile technologies seriously based on the number of casualties in this crisis by reviewing the release dates and launches of applications contributing to the COVID-19 problem (Lalmuanawma et al. 2020). It can be seen that most of the countries that produce these applications started operating in "April and May." In the meantime, only three countries, Austria, Singapore, and Israel, contributed to the COVID-19 crisis in their region with this technology in March and about a month and a half earlier than other countries.

As shown in Table 2, different countries have taken a step forward in software technologies to control diseases such as COVID-19. Each of them tries to manage and evaluate the condition with a part of artificial intelligence divisions. As mentioned in the previous part related to Germany, the application that was run in that country was also implemented on a smartwatch and used in other technologies such as Bluetooth and other sensors in a smartphone. For example, a program in Ghana is applied to study the population in each region. City-wide video surveillance cameras monitor each area of the city's population and display it online on the mobile platform. It allows people to check the area's population before leaving home or work for essentials (Whitelaw et al. 2020, Wang et al. 2021a, 2021b). Artificial intelligence and big data can be highly effective in education, especially in preventing COVID-19 disease. Big data come with three attributes: speed, volume, and variety; each of which can be interpreted as follows:

- Speed in terms of information processing

- Volume in terms of the high amount of data in each process

- Diversity in terms of the number of different sources and channels that can produce big data

There are different types of big data that are divided into three categories based on their source type:

- Imaging-based data (e.g., data mining, extracting highdimensional information from images)

- Data based on wearable sensors

- Digital and computational data by smartphones and the Internet 
Table 2 Some call tracking applications in different countries with the necessary permissions (Whitelaw et al. 2020, Lalmuanawma et al. 2020, Heidel et. al, 2020)

\begin{tabular}{lll}
\hline Call tracking app name Country & $\begin{array}{l}\text { Necessary } \\
\text { permissions to } \\
\text { run the program }\end{array}$
\end{tabular}

Ketju (Shen et al. 2020) Finland
ViruSafe (Lalmuanawma Bulgaria
et al. 2020;
Virussafe 2020)

CovTracer (Covtracer, Cyprus
2020; Lalmuanawma
et al. 2020)
Immuni (Immuni, 2020; Italy
Lalmuanawma et al.
2020)

Bluetooth

The app works
with Bluetooth to track people concerning their privacy to prevent coronavirus disease

Internet, location, This program camera, works through flashlight, GPS and tries accounts to prevent coronavirus disease in the population of the region

Memory card, The app sends location, notifications to writing on the people who memory card, have been Internet, diagnosed with account coronavirus synchronization with GPS tracking

Bluetooth, This app does not location, collect any Internet access GPS-based data, such as private information

The program works via Bluetooth and can also be used to communicate with a general practitioner in acute symptoms

$\begin{array}{lll}\text { HSE COVID-19 App } & \text { Ireland } & \begin{array}{c}\text { Bluetooth, view } \\ \text { network } \\ \text { (HSE.Covid19app- } \\ \text { connections }\end{array}\end{array}$

CoronApp (CoronApp, 2020; Lalmuanawma

Columbia Access location, contacts, contact information, Bluetooth, prevent the

et al. 2020)
Table 2 (continued)

$\begin{array}{lll}\text { Call tracking app name Country } & \begin{array}{l}\text { Necessary } \\ \text { permissions to } \\ \text { run the program }\end{array}\end{array}$

\begin{tabular}{|c|c|c|c|}
\hline & & $\begin{array}{l}\text { device from } \\
\text { falling asleep }\end{array}$ & $\begin{array}{l}\text { tries to provide } \\
\text { solutions and } \\
\text { send health aid } \\
\text { by filling in } \\
\text { information } \\
\text { such as family } \\
\text { members' } \\
\text { symptoms }\end{array}$ \\
\hline $\begin{array}{l}\text { StopCOVID } \\
\text { (Lalmuanawma et al. } \\
\text { 2020; StopCovid, } \\
\text { 2020) }\end{array}$ & France & $\begin{array}{l}\text { Access to location, } \\
\text { camera, } \\
\text { network, } \\
\text { Bluetooth }\end{array}$ & $\begin{array}{l}\text { This app warns } \\
\text { you when you } \\
\text { are near people } \\
\text { with recent } \\
\text { positive } \\
\text { coronavirus } \\
\text { tests. While } \\
\text { protecting the } \\
\text { privacy of the } \\
\text { user, the alarm } \\
\text { is sent } \\
\text { anonymously }\end{array}$ \\
\hline $\begin{array}{l}\text { Mask.ir (Lalmuanawma } \\
\text { et al. 2020; Mask.ir, } \\
\text { 2020) }\end{array}$ & Iran & $\begin{array}{l}\text { Vibration control, } \\
\text { network access, } \\
\text { run at startup, } \\
\text { approximate } \\
\text { and accurate } \\
\text { locations based } \\
\text { on network and } \\
\text { GPS, camera, } \\
\text { Bluetooth }\end{array}$ & $\begin{array}{l}\text { In this program, } \\
\text { you can see the } \\
\text { map of } \\
\text { coronavirus } \\
\text { infection in } \\
\text { your place. In } \\
\text { terms of } \\
\text { population and } \\
\text { then complete } \\
\text { the corona test } \\
\text { information or } \\
\text { find out } \\
\text { through the } \\
\text { program if you } \\
\text { have been in } \\
\text { contact with } \\
\text { people who } \\
\text { have had } \\
\text { coronavirus }\end{array}$ \\
\hline $\begin{array}{l}\text { Smittestopp } \\
\text { (Lalmuanawma et al. } \\
\text { 2020; Smittestopp, } \\
\text { 2020) }\end{array}$ & Norway & $\begin{array}{c}\text { Location access, } \\
\text { Bluetooth }\end{array}$ & $\begin{array}{l}\text { The program } \\
\text { reminds you of } \\
\text { the essential } \\
\text { health tips } \\
\text { when you are } \\
\text { near a person } \\
\text { whose test is } \\
\text { positive }\end{array}$ \\
\hline $\begin{array}{l}\text { Ehteraz (Ehteraz, 2020; } \\
\text { Lalmuanawma et al. } \\
\text { 2020) }\end{array}$ & Qatar & $\begin{array}{l}\text { Memory card } \\
\text { access, delete or } \\
\text { change } \\
\text { memory card, } \\
\text { direct call, } \\
\text { location access, } \\
\text { GPS, Internet } \\
\text { access, prevent } \\
\text { the device from } \\
\text { falling asleep }\end{array}$ & $\begin{array}{l}\text { We are notifying } \\
\text { and providing } \\
\text { education and } \\
\text { health tips to } \\
\text { the people and } \\
\text { prevention of } \\
\text { COVID-19 }\end{array}$ \\
\hline
\end{tabular}


Any style of this data can be effective in treating COVID19 (see Fig. 2). These issues can be necessarily provided by various valuable software in the previous section on corona outbreaks, or the data type can be changed (Bragazzi et al. 2020). ICT is a "helper" that helps disseminate information about the outbreak to large segments of the worldwide population in ways that would be impossible without it. Educators and administrators must be best ready to use ICTs in education throughout the COVID-19 crisis and beyond. This crisis is the perfect opportunity for government-led projects in schools to try out new ways to reach out to kids, learn from other nations, and incorporate practical techniques into regular education. Also, to generate practical student learning experiences, digital technologies must be integrated into sound instructional programs. Governments must undertake the required preparations to better map teaching and learning demands in future educational crises. This necessitates collecting comprehensive survey data on ICT use in schools as a necessary first step in adequately guiding policymaking. The media, particularly social media, can also inform pupils about the virus and basic hygiene. An animated music video advocating handwashing and other preventive steps to guard against the virus has gone popular in Vietnam.

\section{Technology in production and industry}

As the business relies more on technology, new production techniques such as 3D printers and industrial automation have increased in factories since the advent of the COVID-19. Moreover, import incentives have been declined. During this period, smartphones became increasingly widespread and accelerated digital globalization (Schilirò 2020). The global economy has been affected strongly by the outbreak of the corona. For instance, industries such as tourism, aviation, industry, and manufacturing have suffered in the 3 months of the disease since the supply chain management of sectors such as automobiles and electronics faced problems with the closure of international flights. The lack of supply of spare parts worldwide is among them. The coronavirus had the most significant impact on the manufacturing industry in China, the USA, and Germany (Cai and Luo 2020). COVID-19 pandemic and the effect on industrial parts around the world is an example in India. The lockdown has caused labor shortages around the country, which has increased transportation options' resource limitations. Businesses that rely on a "just in time" or "restricted inventory" approach are likely to be disrupted by delayed supplies. Other enterprises and other services have also been shut down, exacerbating the situation. Due to the complete suspension of public transportation, personnel responsible for handling and delivering essential commodities and supplies must now walk to work. The same is particularly exhausting for people living on the fringes of the informal economy, resulting in more low productivity. As indicated in Table 3, if the virus is present in communities for a long time, the expert's knowledge becomes more about this virus. This virus is accompanied by alterations every moment and changes its symptoms. It can be said that the importance of artificial intelligence and digital style on the life of the industry is the only industry the effects of which are visible in the short term, and there is no need for a long time to discover the truths.

Fig. 2 Big data and its defined features

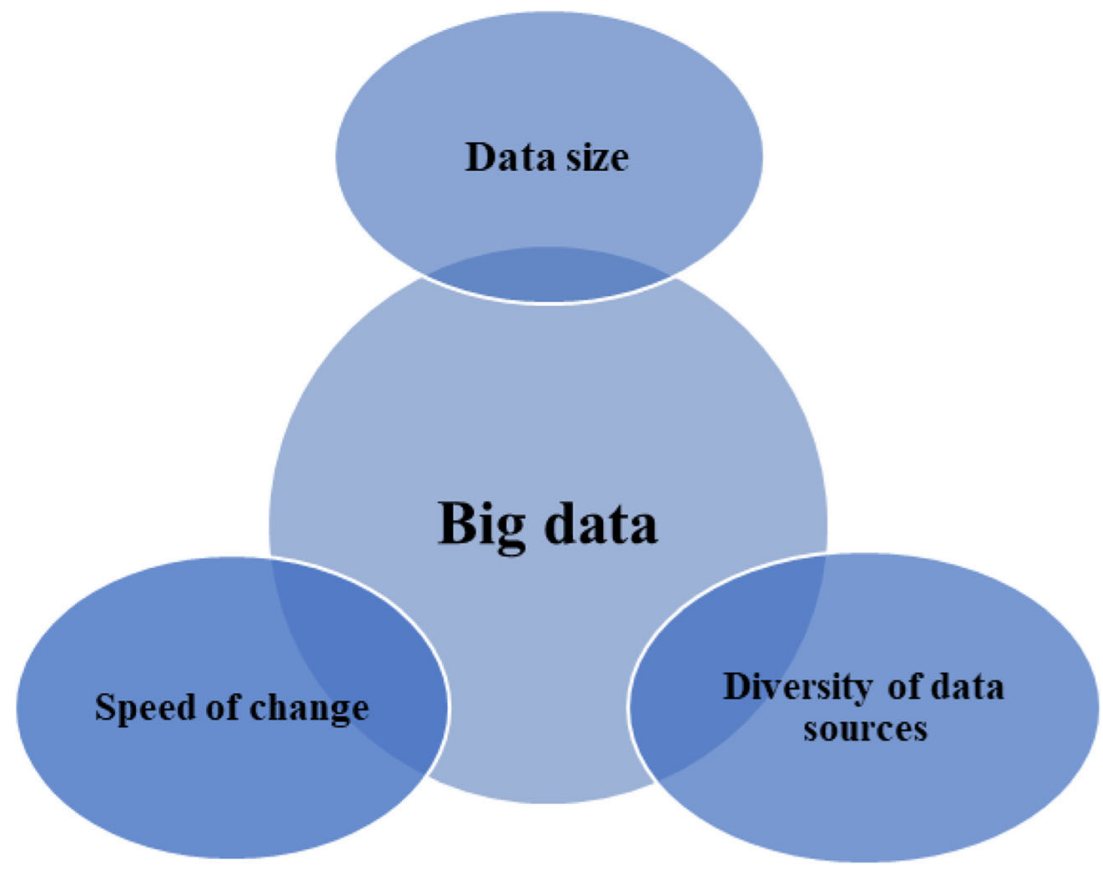


Table 3 Applications of digitization if COVID-19 continues to be prevalent

\begin{tabular}{|c|c|c|}
\hline Period & Application & Description \\
\hline $\begin{array}{l}\text { Short-term } \\
\text { (weekly) }\end{array}$ & Reduce virus outbreak & $\begin{array}{l}\text { Without AI-related } \\
\text { technologies, the } \\
\text { chances of getting the } \\
\text { virus are incredibly high }\end{array}$ \\
\hline $\begin{array}{l}\text { Medium-term } \\
\text { (monthly } \\
\text { and } \\
\text { seasonal) }\end{array}$ & $\begin{array}{l}\text { Diagnosis of the virus } \\
\text { before the onset of } \\
\text { severe symptoms }\end{array}$ & $\begin{array}{l}\text { With city-wide image pro- } \\
\text { cessing cameras, the city } \\
\text { can be placed in demo- } \\
\text { graphic categories, and } \\
\text { the signs of the people } \\
\text { can be monitored. The } \\
\text { affected people can be } \\
\text { immediately directed to } \\
\text { the medical and health } \\
\text { centers }\end{array}$ \\
\hline $\begin{array}{l}\text { Long-term } \\
\quad \text { (annual or } \\
\text { more) }\end{array}$ & $\begin{array}{l}\text { Diagnose, control, and } \\
\text { improve patients or } \\
\text { people at risk of catching } \\
\text { the virus }\end{array}$ & $\begin{array}{l}\text { With this disease's } \\
\text { existence for a year, the } \\
\text { symptoms of this disease } \\
\text { have been placed in the } \\
\text { form of a database and } \\
\text { have been made } \\
\text { available to all scientists, } \\
\text { etc. All the ways of } \\
\text { showing the symptoms } \\
\text { are evaluated using this } \\
\text { database. Also, it is } \\
\text { introduced to the people } \\
\text { in the form of devices } \\
\text { and health-oriented tools }\end{array}$ \\
\hline
\end{tabular}

\section{Applications of digitalization on food and agricultural industries}

In the last 20 years, scientists and physicians have shown more interest in artificial intelligence technologies. First of all, many have attempted to provide a precise definition of artificial intelligence. According to some authors, artificial intelligence is a machine's ability to decode and understand input in an intelligent system. Some believe that artificial intelligence is a new way to manage information in a business model (Lüdeke-Freund 2010). Among the industries, the food industry is also of great importance. In situations similar to this, the need for proper nutrition for a growing population increases. This need interacts directly with systems in the field of agricultural and food sustainability. That is why numerous companies create activities to use artificial intelligence technologies to solve multiple problems and save valuable energy resources. The condition for accepting these technologies in process management is to possess sustainable business models (SBM), which can positively affect the whole system without harming the environment and society (Lüdeke-Freund 2010; Stevens and Shearmur 2020). According to Fig. 3, deep learning, computer vision, physical and software robots, and processing are the major technologies among artificial intelligence technologies that improve industries' quality and performance. Machine vision and deep learning is a method to analyze data, which builds analytical models for a system and is based on the fact that the system can understand the information from the data, identify the models alone, and make the final decision with minimal human intervention. For instance, in the agricultural sector, programs have been developed with artificial intelligence technology, which can detect plant pests with photography (Di Vaio et al. 2020).

Physical and software robots are advanced machines that can solve small and large problems. For example, most people know robotic agriculture, in which they speed up tasks such as weeding or packing fruits. Robots are valuable assets allowing farmers to use their processing information about their profession to obtain various data such as temperature, humidity, fertilizer, soil condition, and water consumption and receive and control them through the robot by optimizing them in the next step (Di Vaio et al. 2020).

Artificial intelligence has other applications in the food industry as follows:

- Sorting food products

- Improving product quality

- Ensuring compliance with health standards

- Preparing and producing drinks

A successful example is the Kankan company; they continuously work to create intelligent solutions to improve health. The system, which can also be used in restaurants, uses face recognition and object recognition cameras to monitor workers to see if workers wear cooking hats and masks following food hygiene laws. Moreover, this software extracts and sends all the images to the management for review (Di Vaio et al. 2020). Digitalization is hugely influential in the industry, especially in the agricultural sector, accounting for half of the world's water consumption (see Table 4). Nowadays, drones are used in farms and agricultural sectors for the reasons as following:

- The possibility of a complete assessment of the ripening status of a fruit

- Irrigation

- Timely use for herbicides and pesticides

These factors have reduced environmental hazards for humans and agricultural products (Di Vaio et al. 2020). 
Fig. 3 The main parts of artificial intelligence

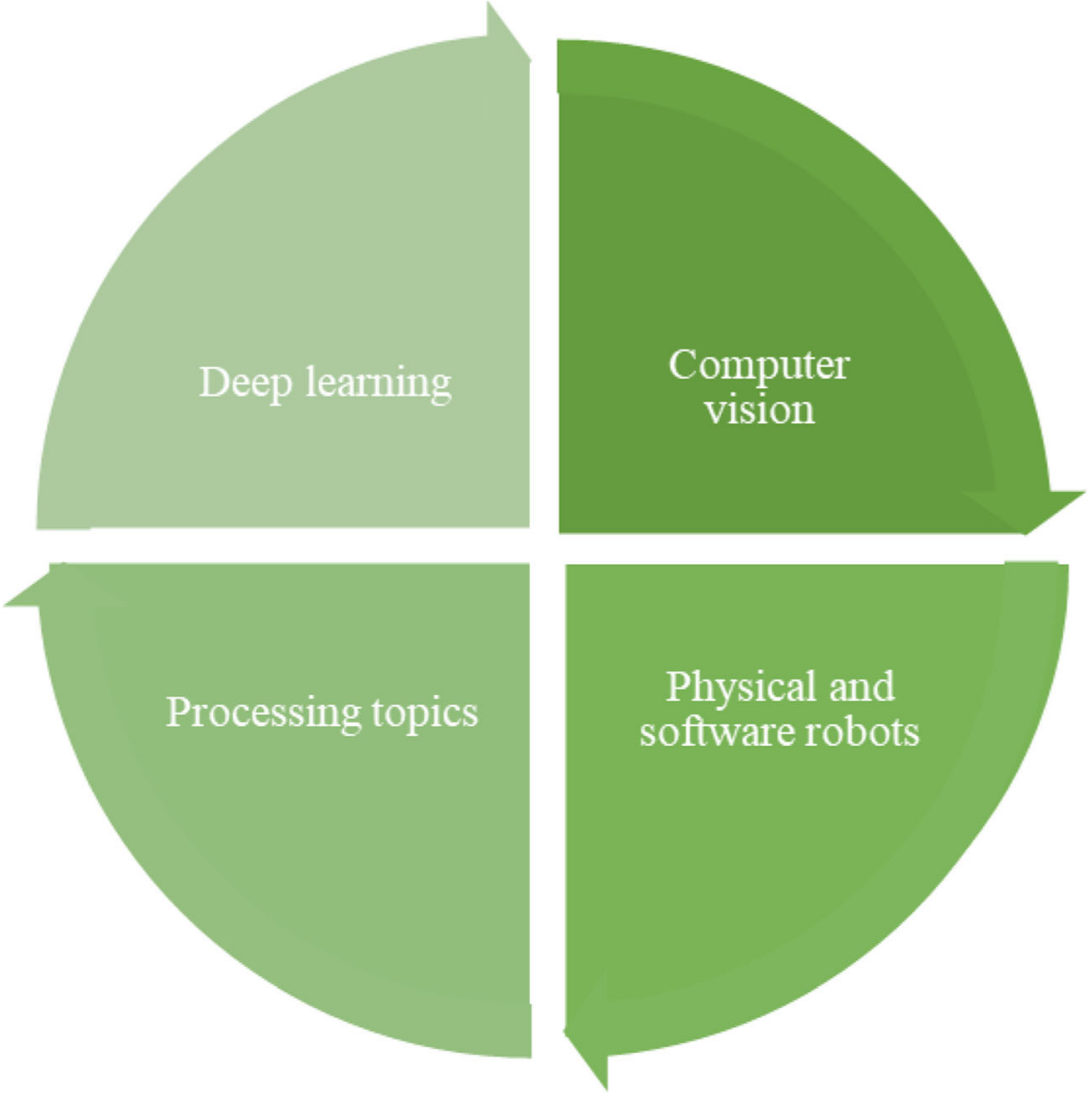

\section{Methodology of applications on energy}

Pandemics triggered by COVID-19 spread to almost every country on the planet. Because energy is one of the most important aspects of modern life, it has been heavily influenced. During the pandemics, a slew of research and analyses developed, each focusing on a different component. However, post-pandemic development will be an essential factor. COVID-19 reached almost every country on the planet. Because energy is one of the most important aspects of modern life, it has been heavily influenced. The authors have attempted to investigate the effect of digitalization on education, treatment, and industry by examining various sources. Undoubtedly, renewable and non-renewable energies and resources have benefited from artificial intelligence and digital style advantages.

\section{COVID-19 and its energy challenges}

COVID-19 revolutionized the energy sector and posed challenges, increasing countries' interest in renewable energy technology. Meanwhile, due to the lack of financial and development resources in African countries, many countries began to import solar and wind energy technologies (Gebreslassie 2020). There are two challenges for customers of renewable sectors: (1) consumer ignorance and (2) lack of initial capital. Most customers are in this situation, and the vacancy of government advertising and promotion policies becomes tangible. The plastics industry is one of the oilrelated industries. After the outbreak of COVID-19, there was a sudden increase in demand and use of plastic products to protect the general public, patients, healthcare workers, and services. Extensive use of such products causes various problems both in terms of supply and disposal of waste, and the vital point is that most of these products are contaminated with the disease or suspected of having the disease, which must be staved off very carefully (Klemeš et al. 2020). Nowadays, artificial intelligence is used for this separation of waste. These systems are installed in waste disposal plants and can effectively waste separation and recycling and recycling speed (Vanapalli et al. 2021).

In the USA, more than 300 drilling rigs were shut down, the country in which the significant oil power is provided through shale oil from 2014 to 2019 with a value of $\$ 100$ oil in 2011 that became an attractive and profitable price for the country. In the context of the COVID-19 crisis, the USA is now being challenged by the low income of this oil in the oil industry's low market demand after the coronavirus epidemic (Jefferson 2020). Venezuela faces US sanctions in addition to low demand for this oil and soft exports because the crude oil produced in this country is heavy and must be diluted to pass through pipelines by factors such as naphtha. The USA has 
Table 4 A review of some work done in the food and agricultural industries with digital style and artificial intelligence

\begin{tabular}{|c|c|c|c|c|}
\hline Author & Year & Purpose & Methods & Conclusion \\
\hline $\begin{array}{l}\text { (Chen et al. } \\
2020)\end{array}$ & 2020 & $\begin{array}{l}\text { Investigation of blockchain-based e- } \\
\text {-agriculture environment }\end{array}$ & $\begin{array}{l}\text { The blockchain network automatically } \\
\text { collects and loads data through various } \\
\text { smart devices, connects orchards and } \\
\text { farms to an integrated network, and } \\
\text { reviews unripe fruits intelligently }\end{array}$ & $\begin{array}{l}\text { Smartphones make farms smarter with } \\
\text { blockchain technology and help } \\
\text { agricultural projects achieve a digital } \\
\text { farming style }\end{array}$ \\
\hline $\begin{array}{l}\text { (Sarker et al. } \\
\text { 2019) }\end{array}$ & 2019 & $\begin{array}{l}\text { Addressing how big data technology } \\
\text { contributes to digital agriculture in } \\
\text { terms of sustainable farm } \\
\text { management }\end{array}$ & $\begin{array}{l}\text { Reviewing the previous research and } \\
\text { studies in the field of big data and the } \\
\text { most optimal use of them }\end{array}$ & $\begin{array}{l}\text { This technology is used to produce } \\
\text { livestock products, crops, fisheries, } \\
\text { and management in the distribution of } \\
\text { these products }\end{array}$ \\
\hline (Renda 2019) & 2019 & $\begin{array}{l}\text { Providing an overview of the Internet } \\
\text { of Things (IoT) applications in agri- } \\
\text { culture }\end{array}$ & $\begin{array}{l}\text { We consider IoT-based software pro- } \\
\text { grams for agriculture on the market, } \\
\text { IoT-based devices used in agriculture, } \\
\text { and the benefits offered by these types } \\
\text { of technologies }\end{array}$ & $\begin{array}{l}\text { Evaluation and improvement of irrigation } \\
\text { systems, remote monitoring, cold } \\
\text { protection systems, and fertilizer } \\
\text { systems in orchards and farms }\end{array}$ \\
\hline $\begin{array}{l}\text { (Gómez-Chabla } \\
\text { et al. 2019) }\end{array}$ & 2019 & $\begin{array}{l}\text { Intelligent food products with } \\
\text { blockchain technology and artificial } \\
\text { intelligence }\end{array}$ & $\begin{array}{l}\text { The use of artificial intelligence and IoT } \\
\text { along with big data measurement and } \\
\text { analysis }\end{array}$ & $\begin{array}{l}\text { Less intervention of human resources in } \\
\text { food and increasing efficiency and } \\
\text { speed in harvesting and distribution of } \\
\text { agricultural products }\end{array}$ \\
\hline $\begin{array}{l}\text { (Talaviya et al. } \\
\text { 2020) }\end{array}$ & 2020 & $\begin{array}{l}\text { Implementation of artificial } \\
\text { intelligence in agriculture to } \\
\text { optimize irrigation and pesticides in } \\
\text { orchards }\end{array}$ & $\begin{array}{l}\text { Pest control and irrigation were } \\
\text { performed manually in the traditional } \\
\text { way, but in this case, digital strategies } \\
\text { are applied to study plants, texture, and } \\
\text { soil type }\end{array}$ & $\begin{array}{l}\text { These technologies are utilized to save } \\
\text { fields and gardens and soil fertility by } \\
\text { saving water consumption }\end{array}$ \\
\hline $\begin{array}{l}\text { (Pathan et al. } \\
\text { 2020) }\end{array}$ & 2020 & $\begin{array}{l}\text { Investigation of different applications } \\
\text { of artificial intelligence in } \\
\text { agriculture to investigate the } \\
\text { presence of pests in the early stages }\end{array}$ & $\begin{array}{l}\text { With the help of image processing } \\
\text { software, artificial neural networks, } \\
\text { and many other tools, the pest can be } \\
\text { detected early in the plant }\end{array}$ & $\begin{array}{l}\text { Due to the detection of pests in the early } \\
\text { stages, the product's health can be } \\
\text { controlled, and high-quality products } \\
\text { can be achieved with minimal losses }\end{array}$ \\
\hline (Sabanci 2020) & 2019 & $\begin{array}{l}\text { Identification of wheat grains damaged } \\
\text { by sunlight and their filter in crop } \\
\text { distribution }\end{array}$ & $\begin{array}{l}\text { These grains are seen using artificial } \\
\text { neural networks and } 17 \text { visual features } \\
\text { with image processing techniques }\end{array}$ & $\begin{array}{l}\text { This algorithm has significantly } \\
\text { improved the accuracy of detecting } \\
\text { damaged grains }\end{array}$ \\
\hline $\begin{array}{l}\text { (Norasma et al. } \\
\text { 2019) }\end{array}$ & 2019 & $\begin{array}{l}\text { Better quality and data analysis based } \\
\text { on agricultural drones }\end{array}$ & $\begin{array}{l}\text { A review of previous studies and } \\
\text { applications of drones in agriculture } \\
\text { and pesticides }\end{array}$ & Improving the quality of farm products \\
\hline $\begin{array}{l}\text { (Tsolakis et al. } \\
\text { 2019) }\end{array}$ & 2019 & $\begin{array}{l}\text { Tool development for simulating farm } \\
\text { management and enabling } \\
\text { agricultural producers to apply } \\
\text { advanced robotic technologies to } \\
\text { their farms }\end{array}$ & $\begin{array}{l}\text { First, an essential classification of system } \\
\text { review studies is performed, and then } \\
\text { the robotic process is created using } \\
\text { artificial intelligence analysis }\end{array}$ & $\begin{array}{l}\text { This process can be used to ensure } \\
\text { product quality before damage occurs }\end{array}$ \\
\hline $\begin{array}{l}\text { (Gonzalez Viejo } \\
\text { et al. 2019) }\end{array}$ & 2019 & $\begin{array}{l}\text { Quality assessment of beverages in the } \\
\text { food industry }\end{array}$ & $\begin{array}{l}\text { Machine learning processes and artificial } \\
\text { intelligence and biometric effects are } \\
\text { some of the methods of this research }\end{array}$ & $\begin{array}{l}\text { To monitor, guarantee, and control } \\
\text { quality and standard production of } \\
\text { beverage products }\end{array}$ \\
\hline
\end{tabular}

imposed sanctions on the export of diluents to the country, and the government is not in a favorable position in terms of energy in the post-COVID-19 era (Jefferson 2020). In Nigeria, with relatively heavy oil similar to Venezuela, it is clear that the country cannot cope with the COVID-19 energy crisis. The government has discounted $\$ 4$ a barrel since the end of April 2020 and has not sold more than half of its oil capacity so far. In Canada, despite possessing several light oil fields, since the end of March 2020, it was announced that the country's economy is on the verge of recession. The Alberta Saskatchewan region, known as the heart of Canada's oil industry, is anticipated to lose more than 200,000 jobs and reduce its oil production capacity by 25 percent. In Saudi
Arabia, if there was no war or other conflict in the region, the country could control the situation after the crisis by owning foreign exchange reserves from oil; however, this country also faces serious problems to pay employees' salaries (Jefferson 2020). As the challenges of COVID-19 on different countries were briefly reviewed above, the authors in this article intend to examine the impact of the crisis of this virus in the field of energy in Iran. As shown in Figure 4, the main effects of COVID-19 on the energy sector in Iran include those that can be seen in the chart.

COVID-19 in the field of oil and gas energy in Iran has caused the following effects: (a) reduction of oil and petroleum product production due to delays in project 
Fig. 4 The effects of COVID-19 on energy (oil, gas, and electricity) in Iran

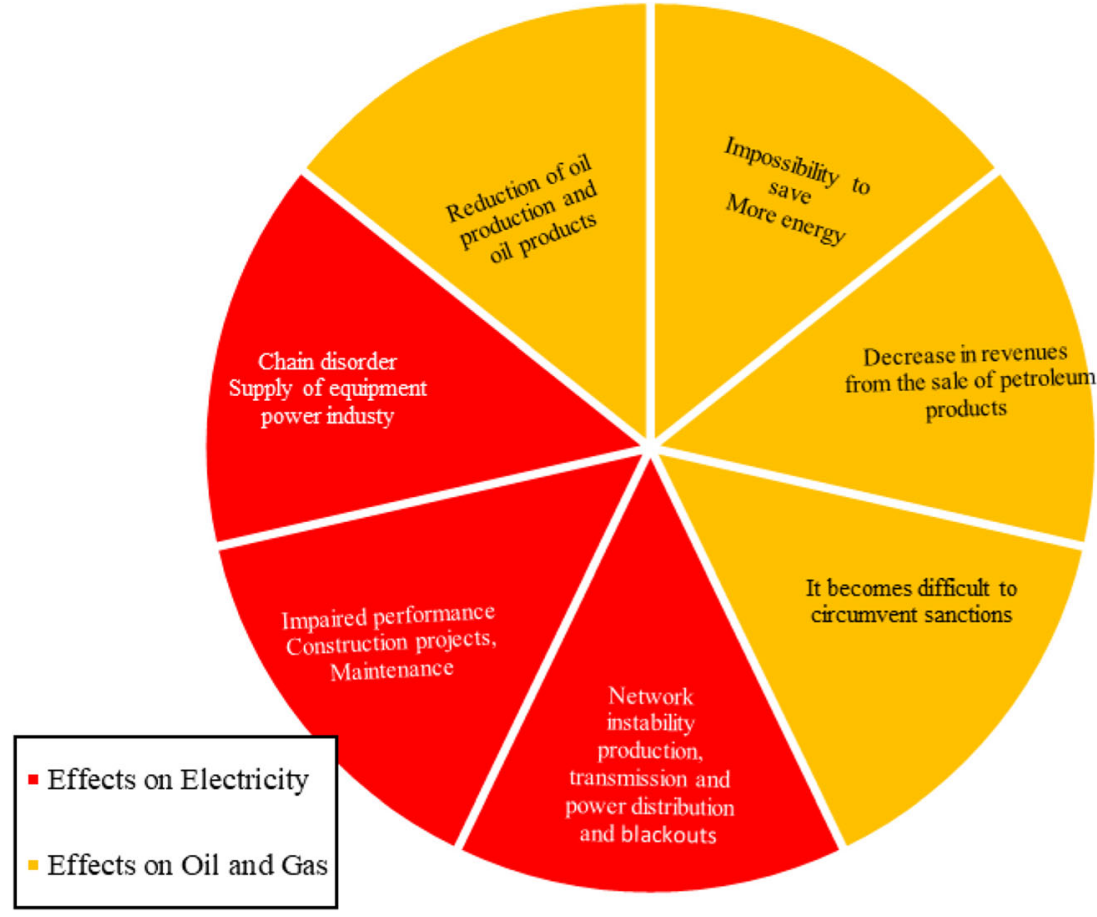

implementation because of reduced required financial resources and decreased level of active human resources and consumption of commercial and industrial sectors, (b) impossibility of storing more gasoline due to reduced consumption and demand for exports, (c) decreased revenues from the sale of petroleum products due to a sharp drop in gasoline and diesel consumption in the transportation sector and reduced domestic consumption due to the semi-closure of industrial and commercial units, and (d) challenges in circumventing sanctions: as global oil demand declines and prices drop, circumventing sanctions will become more difficult because of the cost of their benefits.

COVID-19 has also caused the following outcomes in the field of electricity in Iran: (a) disruption in the supply chain of equipment in the electricity industry due to a 30 to 50 percent reduction in production units' volume and forecast decrease in imports of production units (reduction of 5 to 10 percent); (b) disruption in implementing construction, maintenance, and repair projects for 3 to 6 months to perform the assigned tasks; and (c) instability of electricity generation, transmission and distribution network and occurrence of blackouts due to the lack of timely repairs and maintenance of power plants, and also the possibility of a jump in electricity demand with the resolution of the crisis, return of service, and industrial units to the electricity supply chain (see Table 5). Such challenges could have happened to countries similar to Iran. In the meantime, there are two vacancies: (1) cutting the dependence of government budgets and foreign exchange reserve funds on oil and gas and (2) paying attention to renewable energies, new technologies, and digital style.

\section{Non-renewable energies}

As explained in the section "COVID-19 energy challenges," the oil industry has also contributed to this crisis. This issue has been accompanied by a reduction in transportation with the cessation of global air traffic and a decrease in the number of passengers and goods (www.weforum.org, 2020). The largest share of oil demand is in the transportation sector. In OECD countries, approximately $50 \%$ of this demand is considered for road transport; $8 \%$ for the aviation industry; $14 \%$ for the petrochemical industry; $9 \%$ for the residential, commercial, and agricultural sectors; and $15 \%$ for various industrial activities (Jefferson 2020). In recent years, China has accounted for about 50 percent of world oil demand. Even the demand has declined with the outbreak of COVID19 in this country, an energy-influential country, so that quarantine measures in the country from Wuhan and other cities reduced oil demand by 25 to 30 percent and oil prices were significantly affected. With this situation, a crisis happened in the gold market, which led to further decline due to a lack of planning to control oil energy prices.

Furthermore, in the producers of this valuable capital, namely oil, if the Middle East countries are in crisis with the outbreak of COVID-19, it can seriously affect the oil supply (Norouzi et al. 2020). Consumption of fossil fuels directly influences phenomena such as air pollution in metropolitan areas. Meanwhile, the energy industry is complex and, at the same time, a fundamental part of economic growth in any part of the country. Providing an appropriate model to analyze energy demand and assess various factors' impact can be 
Table 5 A review of the COVID-19 crisis and its energy challenges

\begin{tabular}{|c|c|c|c|c|}
\hline Author & Year & Purpose & Method & Conclusion \\
\hline $\begin{array}{l}\text { (Gebreslassie } \\
\text { 2020) }\end{array}$ & 2020 & $\begin{array}{l}\text { Achieving the sustainable development } \\
\text { goals in Africa to take full advantage } \\
\text { of the opportunities created by the } \\
\text { COVID-19 crisis }\end{array}$ & $\begin{array}{l}\text { Develop and implement the proposed } \\
\text { guidelines for renewable energy }\end{array}$ & $\begin{array}{l}\text { The policies in this article help the } \\
\text { African continent facilitate access to } \\
\text { power and achieve sustainable } \\
\text { development }\end{array}$ \\
\hline
\end{tabular}

(Klemeš et al. 2020 Investigation of waste disposal problems Providing six proposals for the disposal 2020) in medical and health centers under the COVID-19 virus of plastic waste in the future after the COVID-19 crisis

(Vanapalli et al. 2021 We are using the disposal of waste in 2021) medical centers in the conditions of the virus with an artificial intelligence style

(Jefferson 2020) 2020 Improving oil prices and energy indicators in the years after COVID-19

Integration of new sustainable technologies in the current waste management system

Statistical studies on the supply and demand in each country and the change of these parameters after the COVID-19 crisis

(Chen et al. 2020)

2020 They were investigating energy systems and their relationship with individual in-house quarantine and psychological effects among households

This study investigates the dynamics of energy use patterns, climate change issues, and social and psychological factors in a house environment through statistics analysis

(Kulachinskaya 2020 They used a case study of the energy et al. 2020) sector in the Republic of Tatarstan (Russian Federation)

The research method of this study is detailed interviews with senior managers of the energy sector

(Norouzi et al. 2020 The analysis of the effects of COVID-19 In this study, the authors perform a 2020) on electricity and oil demands in China regression and neural network comparison model to analyze the effects of COVID-19 on electricity and oil demand in China

(Wang and $\mathrm{Su}$ 2020a, 2020b)

2020 Investigating the effect of COVID-19 on environmental impacts in a case study in China

Statistical analysis with the support of the meteorological organization in a case study

(Vaka et al. 2020)
2020 The evaluation of the current state of renewable energy in Malaysia and the steps were taken by the country in the field of technology and photovoltaic technologies before the widespread outbreak of COVID-19
Investment information in the photovoltaic sector contained in Malaysia's in-house data and analysis of this information before and after COVID-19
Changes in waste management practices

Developing dynamic waste management without the intervention of human labor by artificial intelligence

The study points out that due to the lack of energy demand in crisis times, a significant increase in oil prices is occurred and requires several years to overcome this challenge

This study can determine access to technologies and energy efficiency devices by considering cultural differences and comparing healthy environments in the house and family and social and psychological factors to investigate such effects with the same people's energy status

The study shows the dynamics of people's energy consumption. It considers the increase of investment in the green energy sector as a precondition for long-term development programs in the Republic of Tatarstan

This study shows that the oil and electricity demand situation concerning the population of infected people is $0.1 \%$ and $0.65 \%$, respectively, which indicates a decrease in energy demand in both sectors. The approach of this study is to pay attention to renewable energy. Extensive surveys of China's major electrical and electronics industries in the COVID-19 outbreak have effectively reduced energy demand by decreasing or shutting down their production line capacity

The results show that with the advent of COVID-19 and quarantine measures and declining coal energy demand, carbon dioxide levels in Chinese air have was dropped. If this situation continues, it could significantly impact global air quality, considering that China is a significant part of its energy consumers

From the current situation in Malaysia, it can be seen that the focus on renewable energy is directed at reducing carbon dioxide, which is not possible without the attention of the 
Table 5 (continued)

\begin{tabular}{|c|c|c|c|c|}
\hline Author & Year & Purpose & Method & Conclusion \\
\hline & & & & $\begin{array}{l}\text { government and incentive plans for } \\
\text { people in the community }\end{array}$ \\
\hline (Eroğlu 2020) & 2020 & $\begin{array}{l}\text { Investigating future studies by } \\
\text { environmental and renewable energy } \\
\text { researchers considering conditions } \\
\text { such as COVID-19 }\end{array}$ & $\begin{array}{l}\text { Statistical reviews and analysis of the } \\
\text { energy and environmental data }\end{array}$ & $\begin{array}{l}\text { Lack of awareness and government } \\
\text { training, technical and investment } \\
\text { support in the renewable energy } \\
\text { sector, and investors' entry in this } \\
\text { sector have faced a severe challenge. } \\
\text { By learning from this crisis, prior } \\
\text { mistakes should be corrected }\end{array}$ \\
\hline
\end{tabular}

effective (www.weforum.org, 2020). Statistical methods and regression models are traditionally applied to model such cases. Recently, methods based on artificial intelligence, such as artificial neural networks (ANN) or nonlinear regression and other hybrid models, are utilized. The advantage of employing artificial neural networks is the strength of these analyses without the need for physical and technical knowledge to communicate between input and output variables. Several studies have reported better efficiency and minor error of artificial neural networks than conventional methods (Fani and Norouzi 2020; Gardner and Dorling 1998; Hagan et al. 1997; Park et al. 1991). Another application of artificial intelligence in energy is load prediction in a future period. Based on time intervals, load forecasting can be divided into three categories: (1) long-term load forecast (next one to ten years), (2) mid-term load forecast (1 month to 1 year), and (3) load forecast in the short term ( $1 \mathrm{~h}$ to 1 day or a week). These predictions can be used for long-term planning of power systems, efficiency, and power systems maintenance, respectively. During the epidemic, network transmission and distribution companies in China utilize big data to estimate network resumption to regulate electricity prices and reduce the cost to businesses (www.cec.org, 2020b). Artificial intelligence plays a crucial role in reducing oil production costs. It is also effective in improving oil fields and the managerial efficiency of companies. Many oil companies have commenced innovative oil field projects to improve decision-making and management ( $\mathrm{Li}$ et al. 2020). For instance, the multidimensional exploration and development platform launched by Schlumberger can achieve automated drilling design using the Internet of Things and other technologies (Nadhan et al. 2018). In another example, AI-based intelligent management assistants, such as oil field robots, virtual oil field assistants, and intelligent oil applications, can replace humans for high-risk tasks and have higher accuracy (Tan and Potts 1995). Based on the application of artificial intelligence in the development of oil fields. It can be concluded that this system will eventually become an intelligent ecosystem and reduce production costs and increase economic profits in cases such as exploration, production, refining, productivity, and quality management ( $\mathrm{Li}$ et al. 2020).
Artificial intelligence is gradually entering all industries, including the energy industry. For instance, a network of big data was set up to investigate faults in power grids for faults quickly. It was used for emergency repairs based on artificial intelligence between January 25 and February 18 in China's Hubei Province at the climax of the COVID-19 outbreak. This process saves an average of $30 \mathrm{~min}$ on power grid repairs (www.cec.org, 2020a). Due to significant reductions in urban transportation and industrial activity, China's energy consumption was significantly reduced during the quarantine period. China is a major consumer of coal, and coal resources dominate the energy consumption structure of individuals. According to researches, coal consumption in China decreased during the COVID-19 crisis. The outbreak of COVID-19 in China has improved air quality in China and significantly impacted reducing carbon dioxide emissions (Wang and Su 2020a, 2020b). Burning fossil fuels such as coal and oil to generate electricity is one of the main causes of global warming and climate change. Many countries are profoundly dependent on fossil fuels, energy demand continues to rise, and it is expected that fossil fuel consumption will increase, resulting in further $\mathrm{CO} 2$ emissions. For this reason, governments around the world are encouraging people to use renewable energies (RE). RE energies are produced from abundant natural sources such as the sun, and wind; hence, they are eco-friendly resources (Vaka et al. 2020).

\section{Introducing power and energy consumption management applications}

As explained in the technology section in education and healthcare, applications have transformed the world into a digital world. Table 6 shows some applications in electricity and energy consumption management, and each of them provides services to users depending on their applications.

\section{Renewable energy}

China is the world's second-largest economy and the first country to be infected with COVID-19. On the other hand, China consumes more energy worldwide. An 
Table 6 Some power and energy management applications worldwide

\begin{tabular}{ll}
\hline App name & Usage \\
\hline $\begin{array}{c}\text { Neurio (www. } \\
\text { neur.io, 2020) }\end{array}$ & $\begin{array}{c}\text { Smart homes, solar } \\
\text { energy }\end{array}$ \\
& \\
MyUsage Mobile & It is connected to smart \\
(MyUsageMob- & electricity meters and \\
ile, 2020) & provides statistics
\end{tabular}

Description

This application works for intelligent homes and helps families save electricity with applications, hardware, and ancillary equipment. The company has several products in the fields of home electricity optimization/energy monitoring of solar systems

This program can be monitored by connecting to smart electricity meters and reporting information $24 \mathrm{~h}$ a day and 7 days a week

$\begin{array}{cl}\text { Sense Home } & \text { Ability to connect to } \\ \text { Energy Monitor } & \begin{array}{l}\text { smart meters, prevent } \\ \text { (Monitor, 2020) }\end{array} \\ & \begin{array}{l}\text { power fluctuations, } \\ \text { process data, and } \\ \text { transfer it to mobile } \\ \text { phones }\end{array}\end{array}$

This software is provided to the user, along with gadgets and hardware. This technology can be installed on smart meters, and you can monitor energy performance and prevent fluctuations using this application. By utilizing this application, we will manage all home appliances' electricity consumption, and their electricity consumption can be measured separately. This program processes the voltage of 1 million times per second and sends all the data intelligently to the Android and iOS operating systems

My HomeSelfe It provides suggestions (MyHomeSelfe, for saving energy 2020) consumption and calculating energy bills

Efergy Ego
(EfergyEgo,
$2020)$
2020)
Table 6 (continued)

\begin{tabular}{|c|c|c|}
\hline App name & Usage & Description \\
\hline & & $\begin{array}{l}\text { smart power sockets } \\
\text { can be connected to } \\
\text { this program. It uses } \\
\text { smart home } \\
\text { technologies, and the } \\
\text { user can manage the } \\
\text { electricity } \\
\text { consumption of the } \\
\text { home }\end{array}$ \\
\hline $\begin{array}{l}\text { Light bulb saver } \\
\text { (Lightbulbsaver, } \\
\text { 2020) }\end{array}$ & $\begin{array}{l}\text { Lighting consumption } \\
\text { management, } \\
\text { providing suggestions } \\
\text { for electricity } \\
\text { consumption }\end{array}$ & $\begin{array}{l}\text { This application runs on } \\
\text { the Android operating } \\
\text { system and can help } \\
\text { users manage power } \\
\text { consumption and } \\
\text { lighting by designing } \\
\text { and simulating power } \\
\text { consumption }\end{array}$ \\
\hline
\end{tabular}

investigation of China's electricity consumption in the first 3 months of the coronavirus outbreak reveals that the share of various industries increased in agriculture by $4 \%$, manufacturing by $3.1 \%$, and services by $19.8 \%$. Meanwhile, urban and rural household electricity consumption increased by 5.3 percent due to quarantine restrictions. It is noteworthy that China has had the highest growth rate among other countries for installing and equipping solar and wind power plants (Nourozi et al. 2020). It also shows that China has taken renewable energy considerably seriously since renewable electricity is more reliable than fossil fuels. Because in case of a crisis or another disease, especially in oil- and gasproducing countries, it can lead to significant shortages in the energy sector for other countries, and China is no exception to this rule (Norouzi et al. 2020).

The effects of COVID-19 have devastated a variety of industries, and solar energy is no exception. Malaysia has allocated approximately $\$ 2.9$ billion in its economic aid package to install power grids and solar panels on rooftops. However, is it possible to install solar panels in any area without planning? In Heo et al.'s (2020) study, the convolution neural network model based on digital modeling is proposed to search for areas with sunlight. The annual amount of the sun in the area is examined to determine suitable locations to install solar panels. For this purpose, this method is used with the CNN approach, using datasets, including topographic information in an area to investigate the state of sunlight and model it with a nonlinear relationship between solar radiation power. Artificial intelligence is also utilized to predict power generation. AI technology is used to indicate the production 
capacity or generation changes of renewable power plants to improve the whole system's stability and security (www.cec.org, 2020b).

\section{Renewable energy opportunities during the COVID-19}

Three styles from the perspective of the current state of the coronavirus crisis with an insight into the future can be observed in Figure 5. Macro plans will be the final vision, and in these circumstances, the plans can be effective. Studies at COVID-19 centers such as Wuhan, Spain, and the USA reveal that air pollution is reduced by $30 \%$ during outbreaks. Cities like Delhi, India, have reported a 40 to 50 percent reduction in air pollution (Gebreslassie 2020). Table 7 shows the significant opportunities after the COVID-19 outbreak in the renewable energy sector, explored in further articles. Satellite imagery by NASA and the European Space Agency reveals that NOX and other pollutants have dropped significantly in China, Europe, and the USA since the outbreak of COVID19. The Chinese government issued calls in April 2020 with a subsidy policy to encourage and commercialize more electric vehicles (B. Wang et al. 2020). Norouzi et al. (2020) provide suggestions for the future of energy in the post-corona circumstances, in which the digitization of this process is also considered. These suggestions include:

1) Development of electricity infrastructure for countries that are exposed to economic and social damage

2) The importance of paying attention to renewable electricity generation
However, in COVID-19, there are reasons to pay special attention to this type of energy. Renewable sources can be used because of their reliability under challenging conditions such as COVID-19. The electricity generation sources are not flexible enough by conventional methods to control this crisis without reducing overall efficiency and putting pressure on the generation and distribution system.

\section{New technologies and blockchain}

Blockchain technologies are among the technologies that have created a digital lifestyle for people. It is a relatively new technology that has been introduced as a transparent, impenetrable, and secure system. COVID-19 was particularly effective in the crisis and has also affected people's health. Utility companies and energy decision-makers are very interested in blockchain technologies. Andoni et al. (2019) fully describe and examine the use and importance of blockchain. Blockchain is formally divided into eight groups according to purpose and field of activity:

- Metering/billing and security

- Cryptocurrencies, tokens, and investment

- Decentralized energy trading

- Green certificates and carbon trading

- Network manager

- IoT, smart devices, automation, and asset management

- Electric e-mobility

- Public initiatives
Fig. 5 Renewable energy opportunities in times of crisis and an insight into the future

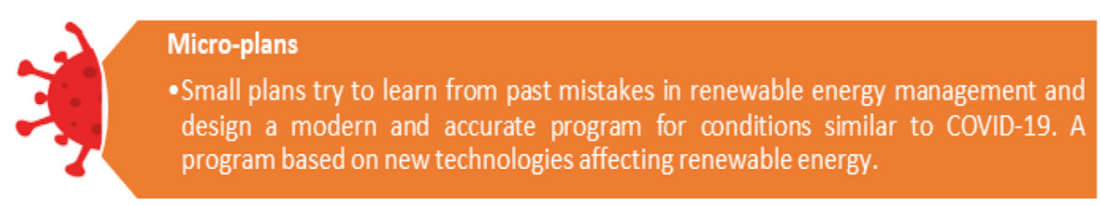

Intermediate-plans

-In the Intermediate plans, an attempt is made to determine a precise strategy to increase the efficiency of methods and programs to reduce the cost of new technologies in the renewable sector. Develop a workforce and experts in this area, as well as take full advantage of machine learning and artificial intelligence capabilities to robotize energy-related processes.

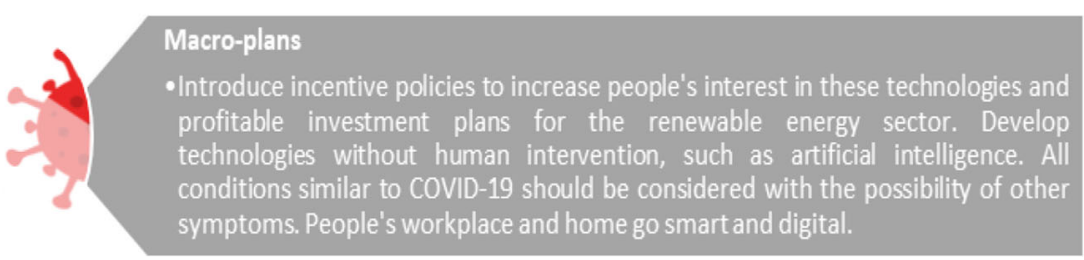


Table 7 Major opportunities after the COVID-19 outbreak in renewable energy

\begin{tabular}{|c|c|c|c|}
\hline Author & Year & Approach & Reasons \\
\hline $\begin{array}{l}\text { (Norouzi et al. } \\
2020 \text { ) }\end{array}$ & 2020 & $\begin{array}{l}\text { 1. Development of } \\
\text { electricity } \\
\text { infrastructure for } \\
\text { countries exposed } \\
\text { to social and } \\
\text { economic } \\
\text { damages } \\
\text { 2. The importance of } \\
\text { paying attention } \\
\text { to renewable } \\
\text { electricity } \\
\text { generation }\end{array}$ & $\begin{array}{l}\text { Reliability of this } \\
\text { type of energy in } \\
\text { critical situations } \\
\text { such as } \\
\text { COVID-19 }\end{array}$ \\
\hline $\begin{array}{l}\text { (B. Wang et al. } \\
\text { 2020) }\end{array}$ & 2020 & $\begin{array}{l}\text { Consideration, } \\
\text { encouragement, } \\
\text { and } \\
\text { commercializa- } \\
\text { tion to the section } \\
\text { of electric } \\
\text { vehicles (Ev) }\end{array}$ & $\begin{array}{l}\text { They are reducing air } \\
\text { pollution and } \\
\text { demand in the fuel } \\
\text { energy sector } \\
\text { Sustainability of } \\
\text { energy supply }\end{array}$ \\
\hline (Vaka et al. 2020) & 2020 & $\begin{array}{l}\text { Consideration of } \\
\text { solar technologies } \\
\text { and long-term in- } \\
\text { vestments for the } \\
\text { dynamism of this } \\
\text { sector in the solar, } \\
\text { wind, and other } \\
\text { sectors }\end{array}$ & $\begin{array}{l}\text { Reduction of air } \\
\text { pollution and } \\
\text { being free from } \\
\text { any damage to the } \\
\text { environment }\end{array}$ \\
\hline (Gebreslassie 2020) & 2020 & $\begin{array}{l}\text { Paying attention to } \\
\text { solar technologies } \\
\text { in Africa, mainly } \\
\text { European } \\
\text { countries } \\
\text { investing in the } \\
\text { construction of } \\
\text { solar panels in the } \\
\text { region }\end{array}$ & $\begin{array}{l}\text { Existence of a very } \\
\text { suitable } \\
\text { investment } \\
\text { platform in this } \\
\text { sector and these } \\
\text { areas }\end{array}$ \\
\hline $\begin{array}{l}\text { (Norouzi et al. } \\
\text { 2020; shoudian. } \\
\text { bjx.com.cn, } \\
\text { 2020; www. } \\
\text { weforum.org, } \\
\text { 2020) }\end{array}$ & 2020 & $\begin{array}{l}\text { Paying attention to } \\
\text { the renewable } \\
\text { energy sector and } \\
\text { investing in } \\
\text { photovoltaic } \\
\text { technologies for } \\
\text { maximum use of } \\
\text { the people, taking } \\
\text { into account the } \\
\text { conditions of the } \\
\text { COVID-19 crisis }\end{array}$ & $\begin{array}{l}\text { Urban and rural } \\
\text { household } \\
\text { electricity } \\
\text { consumption } \\
\text { increased by } 5.3 \\
\text { percent due to } \\
\text { quarantine } \\
\text { restrictions at the } \\
\text { beginning of the } \\
\text { COVID-19 } \\
\text { outbreak, while } \\
\text { China is also the } \\
\text { world's largest } \\
\text { energy consumer }\end{array}$ \\
\hline
\end{tabular}

All of these categories can be effective, and each of them, in turn, can play a role in one part of the energy process, for example, in the first category, which is metering/billing and security. This part of the blockchain has created an opportunity for automatic billing of services and consumers' energy prices. It has also helped manufacturers reduce administrative costs and greatly facilitated communication between the customer and the energy producer, especially in the COVID-19 crisis. This technology is also effective in incentive sections related to energy and helps encourage people to reduce consumptions at peak load times (Andoni et al. 2019).

During this period, the use of cryptocurrencies to pay for energy has attracted many people's interest. For instance, BAS Nederland, a company active in the energy industry, is the first known energy company that approved Bitcoin as a new form of energy bill payment, which was immediately followed by other companies such as Enercity of electricity bill payment. Another example is a startup company in South Africa named Bankymoon that develops technology solutions that integrate Bitcoin payments into intelligent electricity meters (Andoni et al. 2019). Table 8 shows the significant studies on blockchain technology helpful in the COVID-19 crisis. The following are the main findings: The serious research on blockchain technology in the energy sector is rapidly expanding, indicating that blockchain energy is a developing topic of study. Also discussed are the future possibilities of blockchain technology in the energy sector, including energy storage, smart grids, energy Internet, intelligent contracts, peer-to-peer energy, renewable energy, and electric vehicles. Regarding the total number of journals, universities, highly referenced articles, and collaborative ties, a developing nation leads fundamental blockchain research in the energy sector (Wang and Yang 2021). Most of the covered topics are based on data from researchers' data and blockchain technology and are reviewed in articles mentioned in the following.

\section{Finding}

Artificial intelligence (AI) systems have spotted an epidemic of an unknown kind of pneumonia in the People's Republic of China before the world was even aware of the danger presented by the coronavirus (COVID-19). As a result of the outbreak's spread, it has now created a global pandemic. Policymakers, the medical community, and society at general may use AI techniques and technology to help them regulate every step of the problem and its aftermath (detection, prohibition, reply, improvement, and to speed up research). By swiftly evaluating huge amounts of research information, AI technologies and methodologies can assist policymakers and the medical society in better understanding the COVID-19 virus and accelerating research on therapies. AI text and data mining technologies can help researchers learn more about the virus's history, propagation, and diagnosis, as well as management strategies and lessons learned from prior outbreaks. 
Table 8 Significant studies on blockchain technologies related to the control of the COVID-19 crisis

\begin{tabular}{|c|c|c|c|c|}
\hline Author & Year & Purpose & Method & Conclusion \\
\hline Chang et al. [67] & 2020 & $\begin{array}{l}\text { Development of a blockchain-based } \\
\text { platform for user-centric access to } \\
\text { medical data }\end{array}$ & $\begin{array}{l}\text { Applying Ethereum-based intelligent } \\
\text { contracts as well as wearable gad- } \\
\text { gets to assess and measure people's } \\
\text { health }\end{array}$ & $\begin{array}{l}\text { Increasing the scope of medical } \\
\text { information exchange and reducing } \\
\text { the rate of infection through } \\
\text { personal information systems }\end{array}$ \\
\hline Rajesh [68] & 2020 & $\begin{array}{l}\text { They are improving the understanding } \\
\text { of the global model of deep } \\
\text { learning using new and up-to-date } \\
\text { data and using this learning to im- } \\
\text { prove patients' disease with } \\
\text { COVID-19 }\end{array}$ & $\begin{array}{l}\text { The use of patient information and } \\
\text { data in the initial phase and } \\
\text { integration of blockchain } \\
\text { technologies and review of data } \\
\text { among corona treatment hospitals } \\
\text { to identify the pattern }\end{array}$ & $\begin{array}{l}\text { This study finally detects COVID-19 } \\
\text { by identifying CT-scan patterns } \\
\text { using deep convolution neural net- } \\
\text { works (CNN). It can also help di- } \\
\text { agnose COVID-19 patients utiliz- } \\
\text { ing lung screening }\end{array}$ \\
\hline $\begin{array}{l}\text { Mashamba-Thompson } \\
\text { et al. [69] }\end{array}$ & 2020 & $\begin{array}{l}\text { They presented an establishment of } \\
\text { blockchain technology and } \\
\text { artificial intelligence to track } \\
\text { people's calls and control the } \\
\text { COVID-19 crisis at a low cost }\end{array}$ & $\begin{array}{l}\text { The initial stage is completed with a } \\
\text { mobile phone or computer to assess } \\
\text { a person's health, and the user } \\
\text { enters the program with his ID and } \\
\text { transfers his experimental tests to } \\
\text { the program }\end{array}$ & $\begin{array}{l}\text { After the experiments, the data can be } \\
\text { transmitted to other authorities by } \\
\text { artificial intelligence and } \\
\text { blockchain. This technology shows } \\
\text { excellent capability in collecting } \\
\text { information, location, and } \\
\text { reviewing patients' practical } \\
\text { information }\end{array}$ \\
\hline $\begin{array}{l}\text { Bansal et al. } \\
\text { [70] }\end{array}$ & 2020 & $\begin{array}{l}\text { Development of a blockchain-based } \\
\text { platform for people without } \\
\text { COVID-19 and the possibility of } \\
\text { control and presence of these peo- } \\
\text { ple in the community to carry out } \\
\text { social activities }\end{array}$ & $\begin{array}{l}\text { Individuals' public keys can be } \\
\text { exchanged to an anonymous key } \\
\text { by the health center during test } \\
\text { trials by creating blockchain-based } \\
\text { smart contracts. Accordingly, it } \\
\text { identifies the infected individuals } \\
\text { and sends them to various moni- } \\
\text { toring departments for control } \\
\text { while maintaining privacy }\end{array}$ & $\begin{array}{l}\text { The use of blockchain can reduce the } \\
\text { falsification of test reports. It is also } \\
\text { possible to allow people who have } \\
\text { not yet suffered from this disease to } \\
\text { attend different social activities and } \\
\text { filter out other people }\end{array}$ \\
\hline Marbouh et al. [71] & 2020 & $\begin{array}{l}\text { Review of blockchain technology } \\
\text { opportunities in the battle against } \\
\text { COVID-19 }\end{array}$ & $\begin{array}{l}\text { This study implements and evaluates } \\
\text { a blockchain-based system using } \\
\text { Ethereum smart contracts to track } \\
\text { reported data on new morbidity, } \\
\text { mortality, and improved cases from } \\
\text { reputable sources }\end{array}$ & $\begin{array}{l}\text { The proposed solution is } \\
\text { economically feasible and ensures } \\
\text { data integrity, security, and } \\
\text { transparency in data tracking } \\
\text { among contract holders }\end{array}$ \\
\hline
\end{tabular}

- Deep learning (DL) methods can be used to predict the efficacy of old and novel medicines or therapies for COVID-19. AI is being used by a number of organizations to find therapies and produce prototype vaccines. DeepMind and a number of other organizations have utilized DL to predict the design of proteins linked to the SARS-CoV-2 virus, which causes COVID-19.

- Dedicated platforms or fora enable interdisciplinary expertise on AI to be consolidated and shared, especially globally.

- The US government and partner organizations are providing accessibility to datasets in epidemiology, bioinformatics, and molecular modeling, such as the COVID-19 Open Research Dataset Challenge, which provides access approximately 29,000 academic scientific papers for coronavirus and COVID-19.

- Technology corporations such as IBM, Amazon, Google, and Microsoft, as well as individuals providing computer processing power and public-private initiatives like the COVID-19 High Performance Computing Consortium and AI for Health are all contributing computing power to AI.

- It is critical to have a quick diagnosis in order to contain the disease and know how it spreads. AI might aid in the fast diagnosis of COVID-19 patients when used to pictures and symptom information. To guarantee scalability and accuracy, data that is indicative of the whole population should be collected.

- $\mathrm{AI}$ is being employed to forecast the quantity of power produced from renewable sources. As previously said, wind and solar power are very unpredictable, and AI technology can aid in predicting their generating capacity or variations in future periods in order to enhance the overall stability and security of the power system. A three-stage AI algorithm was utilized in several experiments to accurately estimate wind power output $1 \mathrm{~h}$ in the future. 


\section{Discussion}

Since the epidemic of the novel SARS-CoV-2 virus, scientists and medical industries worldwide have been urging people to fight the pandemic by looking for alternative methods of rapid screening and prediction, contact tracing, and forecasting, and vaccine or drug development is more accurate and reliable. Artificial intelligence (AI) is a promising method that several healthcare professionals are using. The findings demonstrated that artificial intelligence enables poverty reduction by improving the collection of poverty-related data via poverty maps, modernizing agriculture education, and expanding financial inclusion in the finance sector. The survey also discovered that $\mathrm{AI}$ is assisting significantly in education and the banking sector, allowing previously excluded people to join the global economy.

The powerful effects of the benefits of digital systems and artificial intelligence on all industries, businesses, energy, etc. were mentioned in the review of the cited articles. However, the point to be noted is the infrastructure issues of these technology models. Such technologies also come with challenges that can lead to inadequate technology transfer and utilization if not well managed. During various studies, most of these technologies face the following challenges, which can be interpreted as "basic challenges."

- Technical limitations

- Lack of support for ICT infrastructure

- Platform errors

- Socio-economic inequalities

- GPS services

- Security risks and privacy issues

By studying each of these factors and reviewing and developing measurement and standardization protocols and privacy laws, the challenges facing new and digital technologies can be reduced (Mbunge, 2020). As a suggestion, in the field of security risks and privacy issues, the entry of technology programs and tools into society can be made subject to a series of restrictions. In this case, legal licenses and entry of products of this group of companies into the community are possible only if it is accompanied by full compliance with regulations and actions such as the following:

- Legal restrictions

- Development of a series of monitoring systems based on the performance of companies

- Encouraging legal companies and introducing violating companies through mass media

- Increasing people's awareness in using products that operate within the framework of privacy

- Prohibiting the publication and distribution of products in this field
On economic and social inequalities, access to energy has always been an essential issue in all continents, including Africa, since only $43 \%$ of sub-Saharan Africa has access to clean and modern electricity. In these areas, there is a lack of Internet access as the driving force behind the artificial intelligence and digital industries or some areas cannot use the Internet due to communication interruptions, high costs of operators, lack of mobile phones, or the lack of electricity towers (Gebreslassie 2020; Ogunleye, Fashoto, Elliot, Arekete, \& Ojewumi, 2018; Watts, 2020). COVID-19 has largely closed people's social connections, and as explained in detail in this article, it has posed numerous challenges to energy, industries, businesses, etc. Finally, it is attempted to review the challenges of each area after COVID-19 and suggest appropriate opportunities in the same place after the crisis. Unquestionably, practical study and effort in these solutions can significantly improve the future world with new technologies.

\section{In the public sector}

\section{Challenges}

1. Basic challenges in societies, which was mentioned in the previous section

2. High cost of new technologies and the inability to buy these products for the poor and middle classes

3. Cultural poverty and lack of knowledge of the basics of information and communication

4. Abuse of ignorant people and reduction of security coefficients of applying these technologies

\section{Opportunities}

1. Producing various applications in the field of communication and social needs of people

2. Improving the process of securing blockchain systems in the communication and banking affairs of individuals

3. Thorough application of virtual reality technologies on people's social communication

4. Promoting and encouraging people to convert a part of their business into cyberspace and the digital world

5. Support and incentive packages and tax exemptions from digital and forward-looking businesses

6. Training and promotion of blockchain systems for ordinary people in the community

7. Reducing and zeroing the fees and network difficulty in the blockchain system 


\section{In the industry sector}

\section{Challenges}

1. Complete or partial closure of many industries, companies, and unemployment

2. Increasing the price of raw materials and the side costs of products

3. Restrictions on transportation and lack of exports and imports in the outbreak of COVID-19 in many countries

4. Bankruptcy and recession in countless industries such as aviation, automobiles, and parts

5. Payment of salaries, insurance, and benefits of employees as well as taxes and payment of energy consumption of factories and industries

\section{Opportunities}

1. Developing payment platforms and receiving the price of products through cryptocurrencies

2. Reducing the price of products if paid through digital wallets

3. The use of artificial intelligence-based monitoring systems based on business in any industry

4. Increasing the promotion of artificial intelligence systems and robotic technologies without hand intervention in factories

5. The use of renewable power systems by considering MPPT algorithms at maximum power

6. The use of machine vision technology and image processing to evaluate the quality of products

\section{In the energy sector}

\section{Challenges}

1. Reducing the demand for energy such as oil

2. Reducing the extent of exports in energy-producing countries

3. Direct referrals of people for energy payment and receiving energy bills and the risk of virus infection

4. Reduction of production capacity in energy

5. Severe drop in energy indexes and economic problems for countries based on oil economy

\section{Opportunities}

1. Upgrading all energy producers to payment systems and receiving energy prices through cryptocurrencies
2. The use of artificial intelligence and machine vision for drilling, exploration, and investigation of energy carrier points

3. The use of artificial intelligence in making maximum use of available resources

4. The use of artificial intelligence in the management and energy process cycles from production to consumption

5. Development of applications for accurate energy reporting at home and work by providing various technical and statistical charts to reduce energy consumption

6. The use of photovoltaic panels by individuals and institutions for home, workplace, etc. and the connection of the entire photovoltaic system, including receiving statistical reports on the production and consumption of the system through the application

7. Building and equipping smart homes connected to mobile phones to turn on and off electrical appliances, etc.

8. The use and expansion of smart electricity meters in homes and other places

\section{Limitation}

There is no one AI approach that can reproduce or better the human mind, despite the fact that several distinct applications have surpassed similar human ability. To put it another way, we only have weak AI right now, not strong AI. These restrictions fragment the aid that technology may provide by concentrating on a pandemic. The more specialized the applications are, the less capable they are of completing a complicated and difficult task. Future studies on more sophisticated NNs, such as deep quantum NNs, may be able to overcome such issues. In addition, the ongoing COVID-19 pandemic has had various degrees of impact on stakeholders throughout the energy business value chain. COVID has had a number of consequences on the energy business, including decreased financial flows, reduced worker availability, and changes in customer behavior. As a result, using AI to anticipate energy use has become challenging.

\section{Conclusion}

The crisis of 2020, the COVID-19 pandemic, was similar to an uninvited guest for all communities, which caused some opportunities regardless of the problems it created. These opportunities were used in the least possible way to overcome this crisis. AI technologies are playing an essential role in fighting and controlling this epidemic. Some of the other Industry 4.0 effective in the treatment of COVID-19 were introduced in Table 1 at the beginning of the article. Undoubtedly, if this uninvited guest had traveled to different 
countries without these technologies, the number of cases and deaths would have been much different from the current values. The impact of these technologies and health, treatment, and disease prevention on other industries and many other fields such as energy was also associated with threats and opportunities. It is a threat because non-renewable energy, such as oil, showed a sharp decline in demand, and their index decreased with the advent of the corona, as described in the COVID-19 Challenges on Energy. Different countries, including Iran as an OPEC member and an influential member of the energy sector, were involved in dealing with this crisis. COVID-19 caused some opportunities since many new businesses were set up in the same environment, and many more were accompanied by increased growth and profitability, including clean and renewable energy technologies. With the outbreak of COVID-19 and the quarantine period, many people were motivated to think about using renewable energies.

On the other hand, other technologies related to renewable energy and artificial intelligence were also accompanied by growth as an example of health-oriented applications, disease tracking, and energy consumption management applications. These are also valuable and practical depending on the needs of people in the community. They also increase the motivation to enter this field in various disciplines, such as programming this technology style and teaching this technology to younger generations. In addition to affecting the people, the COVID19 crisis has been accompanied by threats and opportunities for governments and countries that already recognized the importance of paying attention to new technologies and renewable energy faced with fewer economic and subsistence problems and crises in energy production and distribution. However, countries that desired to pay direct attention to non-renewable energy and the profits from that energy to run their economies faced extensive difficulties that may cause significant damage to the same countries in the event of another crisis similar to COVID-19.

The COVID-19 crisis has affected businesses, technologies, energy, etc., and this impact will be continued. It also influences the oil sector by the OPEC member countries on the oil value index. The challenges of COVID-19 are solved in all areas only by paying attention to new technologies, renewable energy, and artificial intelligence. Then this can be noted that the only condition for having a safe, healthy, dynamic, and economically positive society is to have a digital lifestyle since we may face several other crises in the future. Houses will be the only safe and healthy places at that time. We must think regarding which before the problem occurs. Future research should take numerous paths: new prospects in AI have continually emerged as a result of unique needs, energy efficiency, and savings, as well as reducing and eliminating the environmental load produced by electricity production, transmission, and distribution. It is possible to discuss sustainable energy options and their implications for energy in the event of a future pandemic.

Availability of data and materials Not applicable.

Author contribution Abbas Sharifi: investigation and writing the paper. Mohsen Ahmadi: investigation, funding acquisition, review and editing, and project administration. Ali Ala: review and editing.

\section{Declarations}

Ethical approval Not applicable.

Consent to participate Not applicable.

Consent to publish Not applicable.

Competing interests The authors declare no competing interests.

\section{References}

Andoni M, Robu V, Flynn D, Abram S, Geach D, Jenkins D, McCallum P, Peacock A (2019) Blockchain technology in the energy sector: a systematic review of challenges and opportunities. Renew Sust Energ Rev 100:143-174

Bragazzi NL (2020) Digital technologies-enabled smart manufacturing and industry 4.0 in the post-COVID-19 Era: lessons learnt from a pandemic. Inter J Environ Res Public Health 17(13):4785. https:// doi.org/10.3390/ijerph17134785

Bragazzi NL, Dai H, Damiani G, Behzadifar M, Martini M, Wu J (2020) How big data and artificial intelligence can help better manage the COVID-19 pandemic. Int J Environ Res Public Health 17(9):3176

Cai M, Luo J (2020) Influence of COVID-19 on manufacturing industry and corresponding countermeasures from supply chain perspective. Journal of Shanghai Jiaotong University (Science) 25(4):409-416

Chen Y, Li Y, Li C (2020) Electronic agriculture, blockchain and digital agricultural democratization: origin, theory and application. J Clean Prod 268:122071

Covtracer (2020). https://play.google.com/store/apps/details?id=edu.rise. ihnilatis/. Accessed 28 Sep2020

Di Vaio A, Boccia F, Landriani L, Palladino R (2020) Artificial intelligence in the agri-food system: rethinking sustainable business models in the COVID-19 scenario. Sustainability 12(12):4851

Ehteraz (2020) https://play.google.com/store/apps/details?id=com.moi. covid19\&hl=fa/. Accessed 28 Sep 2020

Eroğlu H (2020) Effects of Covid-19 outbreak on environment and renewable energy sector. Environment, Development and Sustainability, 1-9

Fani M, Norouzi N (2020) Using social and economic indicators for modeling, sensitivity analysis and forecasting the gasoline demand in the transportation sector: an ANN Approach in case study for Tehran metropolis. Iranian Journal of Energy 23(2):71-91

Gardner MW, Dorling S (1998) Artificial neural networks (the multilayer perceptron) - a review of applications in the atmospheric sciences. Atmos Environ 32(14-15):2627-2636

Gebreslassie MG (2020) COVID-19 and energy access: an opportunity or a challenge for the African continent? Energy Res Soc Sci 68: 101677

Gómez-Chabla R, Real-Avilés K, Morán C, Grijalva P, Recalde T (2019) IoT Applications in Agriculture: A Systematic Literature Review. 
In: Valencia-García R, Alcaraz-Mármol G, Cioppo-Morstadt J, Vera-Lucio N, Bucaram-Leverone M (eds) ICT for Agriculture and Environment.CITAMA2019 2019. Advances in Intelligent Systems and Computing, vol 901. Springer, Cham. https://doi.org/ 10.1007/978-3-030-10728-4 8

Gonzalez Viejo C, Torrico DD, Dunshea FR, Fuentes S (2019) Emerging technologies based on artificial intelligence to assess the quality and consumer preference of beverages. Beverages 5(4):62

Hagan MT, Demuth HB, Beale M (1997) Neural network design: PWS Publishing Co

Haleem A, Javaid M (2019) Additive manufacturing applications in industry 4.0: a review. Journal of Industrial Integration and Management 4(04):1930001

Heidel A, Hagist C (2020) Potential benefits and risks resulting from the introduction of health apps and wearables into the German statutory health care system: Scoping review. JMIR mHealth and uHealth 8(9):e16444

Heo J, Jung J, Kim B, Han S (2020) Digital elevation model-based convolutional neural network modeling for searching of high solar energy regions. Appl Energy 262:114588

Immuni (2020). https://play.google.com/store/apps/details?id=it. ministerodellasalute.immuni/. Accessed 28 Sep 2020

Javaid M, Haleem A, Vaishya R, Bahl S, Suman R, Vaish A (2020) Industry 4.0 technologies and their applications in fighting COVID-19 pandemic. Diabetes Metab Syndr Clin Res Rev 14(4): $419-422$

Jefferson M (2020) A crude future? COVID-19s challenges for oil demand, supply and prices. Energy Res Soc Sci 68:101669

Klemeš JJ, Van Fan Y, Tan RR, Jiang P (2020) Minimising the present and future plastic waste, energy and environmental footprints related to COVID-19. Renew Sust Energ Rev 127:109883

Kulachinskaya A, Akhmetova IG, Kulkova VY, Ilyashenko SB (2020) The challenge of the energy sector of Russia during the 2020 COVID-19 pandemic through the example of the Republic of Tatarstan: discussion on the change of open innovation in the energy sector. J Open Innov: Technol Mark Complex 6(3):60

Lalmuanawma S, Hussain J, Chhakchhuak L (2020) Applications of machine learning and artificial intelligence for Covid-19 (SARSCoV-2) pandemic: A review. Chaos, Solitons \& Fractals 139: 110059

Li H, Yu H, Cao N, Tian H, Cheng S (2020) Applications of artificial intelligence in oil and gas development. Archives of Computational Methods in Engineering 28(3):937-949. https://doi.org/10.1007/ s11831-020-09402-8

Lüdeke-Freund F (2010) Towards a Conceptual Framework of 'Business Models for Sustainability (September 19, 2010). In: R. Wever, J. Quist, A. Tukker, J. Woudstra, F. Boons, N. Beute (eds) Knowledge collaboration \& learning for Sustainable innovation. ERSCP-EMSU Conference 2010, The Netherlands, October 25-29, 2010, Available at SSRN: https://ssrn.com/abstract=2189922

Nadhan D, Mayani MG, Rommetveit R (2018) Drilling with digital twins. Paper presented at the IADC/SPE Asia pacific drilling technology conference and exhibition

Naudé W (2020) Artificial intelligence against COVID-19: an early review

Norouzi $\mathrm{N}$ et al (2020) When pandemics impact economies and climate change: Exploring the impacts of COVID-19 on oil and electricity demand in China. Energy Res Soc Sci 68:101654

Norasma C, Fadzilah M, Roslin N, Zanariah Z, Tarmidi Z, Candra F (2019) Unmanned aerial vehicle applications in agriculture. Paper presented at the IOP Conference Series: Materials Science and Engineering
Norouzi N, de Rubens GZ, Choubanpishehzafar S, Enevoldsen P (2020) When pandemics impact economies and climate change: exploring the impacts of COVID-19 on oil and electricity demand in China. Energy Res Soc Sci 68:101654

Ogunleye GO, et al. (2018) Securing and monitoring of Bandwidth usage in multi-agents denial of service environment. Int J Adv Comput Sci Appl 9.9:434-445

Park DC, El-Sharkawi M, Marks R, Atlas L, Damborg M (1991) Electric load forecasting using an artificial neural network. IEEE Trans Power Syst 6(2):442-449

Pathan M, Patel N, Yagnik H, Shah M (2020) Artificial cognition for applications in smart agriculture: a comprehensive review. Artificial Intelligence in Agriculture

Ren J-1, Zhang A-H, Wang X-J (2020) Traditional Chinese medicine for COVID-19 treatment. Pharmacol Res 155:104743

Renda A (2019) The Age of Foodtech: Optimizing the Agri-Food Chain with Digital Technologies. In: Valentini R, Sievenpiper J, Antonelli M, Dembska K (eds) Achieving the sustainable development goals through sustainable food systems. Springer, pp 171-187. https:// doi.org/10.1007/978-3-030-23969-5 10

Sabanci K (2020) Detection of sunn pest-damaged wheat grains using artificial bee colony optimization-based artificial intelligence techniques. J Sci Food Agric 100(2):817-824

Sarker MNI, Islam MS, Ali MA, Islam MS, Salam MA, Mahmud SH (2019) Promoting digital agriculture through big data for sustainable farm management. Int J Innov Appl Stud 25(4):1235-1240

Schilirò D (2020) Towards digital globalization and the covid-19 challenge

Shen M, Wei Y, Li T (2020) Bluetooth-based COVID-19 proximity tracing proposals: an overview. arXiv preprint arXiv 2008:12469

Stevens L, Shearmur RG (2020) The end of location theory? Some implications of micro-work, work trajectories and gig-work for conceptualizing the urban space economy. Geoforum 111:155-164

Talaviya T, Shah D, Patel N, Yagnik H, Shah M (2020) Implementation of artificial intelligence in agriculture for optimisation of irrigation and application of pesticides and herbicides. Artificial Intelligence in Agriculture

Tan A, Potts J (1995) Digital log management system. SPE Computer Applications 7(04):88-90

Tsolakis N, Bechtsis D, Bochtis D (2019) AgROS: a robot operating system based emulation tool for agricultural robotics. Agronomy 9(7):403

Vaka M, Walvekar ,R, Rasheed AK, Khalid M (2020) A review on Malaysia's solar energy pathway towards carbon-neutral Malaysia beyond Covid'19 pandemic. J Cleaner Prod 273:122834. https://doi. org/10.1016/j.jclepro.2020.122834

Vanapalli KR, Sharma HB, Ranjan VP, Samal B, Bhattacharya J, Dubey BK, Goel S (2021) Challenges and strategies for effective plastic waste management during and post COVID-19 pandemic. Sci Total Environ 750:141514

Virussafe (2020). https://play.google.com/store/apps/details?id=io. uslugi.nramobile/. Accessed 28 Sep 2020

Wang Q, Su M (2020a) A preliminary assessment of the impact of COVID-19 on environment-a case study of China. Sci Total Environ 728:138915

Wang Q, Su M (2020b) Integrating blockchain technology into the energy sector-from theory of blockchain to research and application of energy blockchain. Comput Sci Rev 37:100275

Wang Q, Yang X (2021) How do pollutants change post-pandemic? Evidence from changes in five key pollutants in nine Chinese cities most affected by the COVID-19. Environ Res 197:111108 
Wang B, Yang Z, Xuan J, Jiao K (2020) Crises and opportunities in terms of energy and AI technologies during the COVID-19 pandemic. Energy and AI.

Wang Q, Li R, Zhan L (2021a) Blockchain technology in the energy sector: from basic research to real world applications. Computer Science Review 39:100362

Wang Q, Wang S, Jiang XT (2021b) Preventing a rebound in carbon intensity post-COVID-19-lessons learned from the change in carbon intensity before and after the 2008 financial crisis. Sustainable Production and Consumption 27:1841-1856
Watts G (2020) "COVID-19 and the digital divide in the UK." The Lancet Digital Health 2.8: e395-e396

Whitelaw S, Mamas MA, Topol E, Van Spall HGC (2020) Applications of digital technology in COVID-19 pandemic planning and response. The Lancet Digital Health, 2(8):e435-e440. https://doi. org/10.1016/s2589-7500(20)30142-4

Publisher's note Springer Nature remains neutral with regard to jurisdictional claims in published maps and institutional affiliations. 